\title{
Adaptasi Petani So Selence Desa Belo Kecamatan Palibelo Kabupaten Bima
}

\author{
${ }^{*}$ Mochamad Noeryoko ${ }^{1}$ Zulharman ${ }^{2}$ \\ 1,2STKIP Taman Siswa Bima. \\ 1yokonoer78@gmail.com \\ ${ }^{*}$ Coresponding Author
}

Artikel Info

TanggalPublikasi

2019-06-30

Kata Kunci

Petani,

Adaptasi

\section{Abstrak}

Penelitian ini penulis membahas tentang adaptasi petani di So Selence desa Belo kecamatan Palibelo kabupaten Bima adapun tujuan penelitian ini yaitu; (1) Untuk mengetahui keadaan pengairan yang ada di So Selencedesa Belo kecamatan Palibelo kabupaten Bima (2) Untuk mengetahui kegiatan para petani di So Selencedesa Belo kecamatan Palibelo kabupaten Bima pada musim penghujan; (3) Untuk mengetahui kegiatan para petani di So Selencedesa Belo kecamatan Palibelo kabupaten Bima pada musim kemarau. Penelitian ini menggunakan jenis penelitian kualitatif deskriptif, sumber data terdiri dari sumber data sekunder dan sumber data primer. Teknik pengumpulan data dilakukan melalui observasi, wawancara mendalam, juga dokumentasi. Hasil penelitian; (1) Keadaan pengairan di So Selencedesa Belo kecamatan Palibelo kabupaten Bima hanya tersedia hanya pada musim hujan saja; (2) Petani di So Selencedesa Belo kecamatan Palibelo kabupaten Bima pada musim hujan menanam padi; (3) Petani di So Selencedesa Belo kecamatan Palibelo kabupaten Bima pada musim kemarau menanam sayur sayuran, buah-buahan kedelai, kacang tanah, kacang hijau dan jagung.

\section{PENDAHULUAN}

Kabupaten Bima sebagian besar penduduknya bekerja dalam bidang pertanian, selain itu bidang perikanan yaitu nelayan dan petambak, hal ini sesuai dengan karakteristik wilayah kabupaten Bima yang merupakan daerah pegunungan yang dikelilingi oleh laut disebelah utara ada laut Flores, disebelah selatan Samudra Hindia disebelah timur merupakan selat Sape yang berbatasan langsung dengan pulau Flores sementara itu dibagian tengah utara ada teluk Bima yang merupakan daerah yang sesuai untuk usaha tambak bandeng dan produksi garam sementara dibagian selatan ada teluk Waworada sehingga usaha penangkapan ikan juga bisa dilakukan. Usaha pertanian di kabupaten Bima sangat tergantung dari musim karena daerah yang bergunung-gunung sehingga persediaan air untuk sangat terbatas untuk menyuplai kebutuhan pertanian, sehingga tanaman pertanian di gunung hanya di lakukan ketika musim hujan saja karena ketika musim hujan akan kesulitan air. Penulis mengangkat judul penelitian "adaptasi petani so selence desa belo kecamatan palibelo kabupaten bima”, berdasarkan latar belakang diatas maka rumusan masalahnya yaitu. Bagaimana keadaan pengairan yang ada di So Selence desa Belo kecamatan Palibelo kabupaten Bima?, bagaimana kegiatan para petani di So Selence desa Belo kecamatan Palibelo kabupaten Bima pada musim penghujan?, bagaimana kegiatan para petani di So Selence desa Belo kecamatan Palibelo kabupaten Bima pada musim kemarau?.(1) Sementara kajian pustaka adaptasi menurut KKBI berarti penyesuaian terhadap lingkungan, pekerjaan, dan pelajaran, sementara itu So dalam dalam bahasa Bima berarti hamparan tanah pertanian yang luas yang dibatasi oleh batas alam, untuk itu So Selence yang merupakan hamparan tanah pertanian yang terletak di Desa Belo Kecamatan Palibelo Kabupaten Bima. Pertanian sendiri berarti mata pencaharian dalam bentuk bercocok tanam; mata pencarian dalam bentuk mengusahakan tanah dengan tanam-menanam; untuk selanjutnya kajian pustaka yang cocok dengan judul diatas adalah penyesuaian terhadap lingkungan yang ada di hamparan pertanian di desa Belo 
Kecaatan Paibelo untuk mengusahkan tanah tersebut berfungsi sebagai usaha bercocok tanam.(3) Untuk tujuan dari penelitian ini adalah Untuk mengetahui keadaan pengairan yang ada di So Selence desa Belo kecamatan Palibelo kabupaten Bima dan untuk mengetahui kegiatan para petani di So Selence desa Belo kecamatan Palibelo kabupaten Bima pada musim penghujan dan juga untuk mengetahui kegiatan para petani di So Selence desa Belo kecamatan Palibelo kabupaten Bima pada musim kemarau.

\section{METODE PENELITIAN}

Mengacu pada judul penelitian yaitu "Adaptasi Petani Di So Selence Desa Belo Kecamatan Palibelo Kabupaten Bima” maka peneliti menggunakan pendekatan kualitatif deskriptif. Menurut Sugiyono (2006: 15) bahwa metode penelitian kualitatif adalah metode penelitian yang berdasarkan pada filsafat, digunakan untuk meneliti pada kondisi obyek alamiah, dan peneliti sebagai intrumen kunci. Penelitian yang dilaksanakan tergolong dalam jenis penelitian kualitatif, jadi teknik yang dilakukan dalam strategi penelitian ini adalah diawali dengan melakukan wawancara yang mendalam terkait topik yang diteliti.

Sumber data dalam penelitian adalah subyek dari mana data dapat dieroleh (Arikunto, 2002: 107). Sedangkan menurut Moeloeng (2002:157) bahwa sumberdata utama dalam penelitian kualitatif ialah kata-kata dan tindakan, selebihnya adalah data tambahan seperti dokumen dan lain-lain. Dengan demikian, sumber data penelitian yang bersifat kualitatif dalam penelitian ini adalah sebagai berikut (1) sumber dat primer, diperoleh dari hasil penelitian dilapangan secara langsung, dan pihakpihak yang berangkutan dengan masalah yang akan dibahas dalam hal ini adalah petani so selence desa Belo kecamatan Palibelo kabupaten Bima. Untuk memperoleh sumber data primer digunakan teknik wawancara dan observasi. (2) sumber data sekunder, sumber data sekunder adalah sumber data yang diperoleh secara tidak langsung dari informan dilapangan, seperti dokumen dan sebagainya, dokumen dapt berupa buku-buku, literatur lainnya ataupun gambar-gambar yang berhubungan dengan masalah masalah penelitian.

Penelitian disamping perlu menggunakan metode yang tepat, juga perlu memilih alat dan teknik pengumpulan data yang relevan, teknik pengumpulan data sebagai berikut: (1) pengamatan (observasi), diartikan sebagai pengamatan dan pencatatan secara sistematik terhadap gejala yang tampak pada objek penelitian. Pengamatan dan pencatatan yang dilakukan terhadap objek di tempat terjadi dan berlangsungnya peristiwa disebut obsevasi langsung. Sedangkan observasi tidak langsung adalah pengamatan yang dilakukan tidak pada saat berlangsungnya sesuatu yang akan diselidik ( Rachman, 1999: 77). Dalam hal ini peneliti mengobservasi keadaan pengairan So Selence, letak geografis So Slence, jenis tanaman yang ditanam petani di So Selencedesa Belo kecamatan Palibelo kabupaten Bima. Observasi dilakukan sebagai informasi awal dalam penelitian ini guna memperoleh data yang akurat sesuai dengandata yang empiris dibutuhkan penelitian ini.(2) wawancara, adalah percakapan dengan maksud tertentu. Percakapan itu dilakukan oleh dua pihak, yaitu pewawancara yang mengajukan pertanyaan dan yang di wawancarai yang memberikan jawaban atas pertanyaan itu (Moeloeng, 2003: 133). Dalam penelitian ini wawancara dilakukan terhadap petani di So Selence desa Belo kecamatan Palibelo kabupaten Bima. (3) Dokumentasi, teknik dokumentasi adalah mengumpulkan data melalui peninggalan tertulis, seperti arsip-arsip dan termasuk juga buku-buku tentang pendapat, teori, dalil atau hukum-hukum, dan lain-lain yang berhubungan dengan maslah penelitian (Rachman, 1999: 96). Teknik ini, digunakan untuk memperoleh data dokumen atau gambar-gambar foto hasil penelitian yang tampak di lapangan.

Teknik keabsahan data memiliki empat kriteria yaitu kepercayaan, keteralihan, ketergantungan, dan kepastian Untuk keabsahan data penelitian di lapangan perlu (1) keikutsertaan peneliti di lapangan, peneliti dengan perpangjangan keikutsertaannya akan dapat mempelajari kebudayaan dan 
dapat menguji ketidak benaran informasi yang diperoleh, baik yang yang berasal dari diri sendiri maupun dari responden dan membangun kepercayaan subyek (2) Triangulasi, teknik ini dilakukan untuk pemeriksaan keabsahan data yang memanfaatkan sesuatu yang lain di luar data itu untuk keperluan pengecekab atau sebagai pembanding terhadap data itu (Moeloeng, 2002: 178). Pada teknik ini peneliti menguji kebenaran data hasil penelitian dengan menggunakan data yang sudah ada yang sama dengan penelitian yag dilakukan, artinya sebanding apakah ada perselisihan dalam data hasil penelitian misalnya membandingkan hasil wawancara dengan teori terdahulu.

Metode pengolahan data atau teknik analisa data dalam penelitian ini dilakukan secara terus menerus sejak awal sampai akhir penelitian. Analisa data dalam penelitian ini menggunakan teknik deskriptif yang ditekankan pada analisa kualitatif dengan teknik induksi dan deduksi, tidak menutup kemungkinan juga argumentasi (Arikunto, 2002: 15). Analisis data terdiri dari 3 kegiatan, antara lain sebagai berikut: (1) Redukdi data, reduksi data merupakan bentuk analisis yang menajamkan, menggolongkan, mengarahkan, membuang yang tidak perlu, dan mengorganisasi data dengan cara tertentu sehingga simpulan akhir dapat ditarik. Pada tahab reduksi data ini, data yang diklasifikasikan kemudian diseleksi untuk memilih data berlimpah kemudian dipilah dalam rangka menemukan fokus penelitian. (2) penyajian data, penyajian data adalah menampilkan informasi tersusun yang memberi kemungkinan adanyapenarikan kesimpulan dan pengambilan tindakan. Data-data yang telah tersusun kemudian disajikan dalam bentuk analisis sehingga akan tergambar permasalahan yang menjadi obyek kajian. (3) Penarikan kesimpulan, teknik penarikan simpulan adalah langkah yang esensial dalam proses penelitian. Penarikan kesimpulan ini didasarkan atas pengorganisasian informasi yang diperoleh dalam analisis data. Penarikan kesimpulan dalam penelitian ini menggunakan teknik induktif, yaitu teknik penarikan simpulan dari data-dat yang bersifat khusus menuju simpulan yang bersifat umum ( Milles Matthw B. Dan Michael Hubbrman, 1992: 23).

\section{HASIL DAN PEMBAHASAN}

Berdasarkan observasi yang dilakukan peneliti sumber pengairan So Selence berasal dari Dam yang ada di desa Roka yang dialirkan melewati desa persawahan desa Roka dan persawahan desa Talabiu sehingga air yang datang sudah dibagi-bagi untuk kedua areal persawahan tersebut, sementara sumber air dari dam Roka adalahair hujan yang ditampung selama musim hujan, ketika musim hujan petani tidak kesulitan untuk mendapatkan pasokan air yaitu dari air hujan itu sendiri dan pasokan dari dam Roka.

Berdasarkan wawancara dengan petani So Selence yaitu bapak usman mengatakan"Nami ke wati susah oi anae wunga barare palasi wunga panaaire ncoki poda rako oi, tiwara oi mamai" (Kita ini tidak susah dapat air untuk pertanian kita ketika musim hujan tetapi ketika musim kemarau sulit sekali dapat air, tidak ada air yang datang), begitu juga menurut bapak Hasnun mengatakan "Sapodakaina tolo ndaike waur wara lapa raikai oi, pala lapake wara oi wunga bara mpao pa, ndakdina ndaike ncoki raka oi wunga panaiai" (sebenarnya sawa kita sudah ada parit untuk mengalirkan air, akan tetapi parit itu ada air ketika musim hujan saja, sehingga kita ini sulit dat air ketika musim kemarau)

Berdasarkan observasi peneliti ketika musim hujan petani di So Selence menanam padi di areal persawahannya karena pasokan air cukup untuk tanaman padi yang membutuhkan banyak air untuk pertumbuhannya karena air datang dari parit parit yang terhubung dengan dam Roka dan juga dari air hujan yang turun secara langsung ke sawah-sawah mereka. Begitupun hasil wawancara dengan Dae Temo mengatakan "Namike wunga barare ngukda fare, fare ke nee na oi ma mboto loaku mboto hasina"( Ketka musim hujan kita ini tanam padi, karena padi itu butuh air yang cukup, supaya hasilnya bagus)

Berdasarkan observasi peneliti ketika musim kemarau petani di so selence menanam aneka sayuran dan tanaman yang tidak membutuhkan banyak air misalnya jagung, kedelai kacang hijau,kacang tanah. Begitupun hasil wawancara kepada pak Saleh mengatakan "Namike ngukda kaca 
anae wunga panaai ndakeke, oi re ncoki diraka, namike raka oi diesel, bensi diweli, ncoki poda" (Kita ini tanam kacang tanah anak, ketika musim kemarau begini, air susah didapat, air dari pompa diesel jadinya harus beli bensin, pokoknya susah benar ketika musim kemarau untuk dapat air)

Peneliti melakukan wawancara pada bapak Ahmad mengatakan "Wunga panaai ndakeke nami ngukda uta mbeca wara kol, nadu, saha, dimu, wara rau wua ponda, uwi, bojo, melon, semangka, timun mas rau"(Ketika musim kemarau begini kita tanam sayuran ada kol, bayam, cabe, timun ada juga buah labuh, ubi, singkong, melon, semangka, timun mas juga), begitu juga wawancara dengan Husen mengatakan "ma ntenere namike ngukda ma wati ipi butuh oi dikemorikai" (yang pasti kita ini tanam, tanaman yang tidak membutuhkan banyak air untuk pertumbuhannya)

So dalam dalam bahasa Bima berarti hamparan tanah pertanian yang luas yang dibatasi oleh batas alam, untuk itu So Selenceyang merupakan hamparan tanah pertanian yang terletak di Desa Belo Kecamatan Palibelo Kabupaten Bima. Keadaan pengairan ketika musim penghujan tidak ada masalah karena ada air hujan yang langsung masuk kesawah dan juga dari Dam Rokayang sampai ke So Selence. Infrastuktur pengairan di So Selence sebenarnya cukup baik kerena ada saluran irigasi yang sudah dibangun oleh pemerintah dengan adanya parit-parit yang terhubung antara dam Roka sampai dengan persawahan yang ada di So Selence, akan tetapi dengan adanya saluran irigasi tidak menjamin ketersediaan air, karena air yang ada di dam Roka tidak mencukupi sampai dengan musim kemarau, sehingga air tidak ada ketika musim kemarau datang. Hal itu juga dikarenakan jarak antara So Selencedengan dam Roka jarak sekitar 3 KM sehingga air dibagi-bagi untuk areal persawahan yang ada di desa Roka sendiri dan desa Talabiu sehingga air sampai di So Selence desa Belo hanya sedikit dan tidak mampu mengairi areal persawahan ketika musim kemarau tiba. Para petani ketika musim kemarau mendapatka air dari pompa air sehingga menambah beban biaya produksi untuk membuat bor kedalam tanah dan pembelian mensin pompa air untuk menaikan air, selain itu juga ada biaya harian untuk membeli bensin yang dipakai sebagai bahan bakar mesin pompa air.Menurut Mubyarto (1989), dalam ilmu ekonomi dikatakan bahwa petani membandingkan antara hasil yang diharapkan diterima pada hasil panen (penerimaaan/revenue) dengan biaya (cost) yang harus di keluarkannya. Hasil yang diperoleh petani pada saat panen disebut produksi dan biaya yang dikeluarkan disebut biaya produksi. usahatani yang baik biasa disebut sebagai usahatani yang produktif atau efisien.

Petani di So Selence ketika musim hujan tidak banyak mengalami kendala masalah air untuk mengairi sawah mereka dikarenakan air cukup melimpah. Hal itulah yang mendorong petani untuk menanam padi karena padi cukup penting untuk kebutuhan pangan petani itu sendiri selama setahun kedepan. Ketika musim hujan petani akan menanam padi karena ketersediaan yang melimpah sehingga sesuai dengan karakter tanaman padi yang membutuhkan banyak air untuk pertumbuhannya sehingga padi yang sudah ditanam akan tumbuh sehat dan menghasilkan bulir padi yang banyak sehingga menguntungkan para petani di So Selencetersebut.

Keadaan akan berubah ketika datang musim kemarau ketika air yang ada di dam Roka sudah tidak mampu lagi untuk mengairi persawahanSo Selence, petani tidak lagi menanam padi karena padi sangat membutuhkan air dalam pertumbuhannya untuk itu petani di So Selencememanfaatkan pompa air untuk mengangkat air dalam tanah. Tanaman-tanaman yang biasa ditanam yaitu jenis sayursayuran, buah buahan serta tanaman pertanian yang tidak membutuhkan banyak air sehingga kegiatan pertanian tetap berlangsung walaupun dengan keadaan air yang cukup sulit untuk didapat. Sayurmayur yang biasa ditanam yaitu kol, cabe rawit, sawi, labuh dan juga ubi jalar yang diambil daunnya untuk sayuran. Sementara itu buah buahan yang biasa ditanam oleh petani di So Selence yaitu semangka, labu, timun mas, blewa dan juga melon. Selain kedua jenis tersebut petani di So Selence menanam tanaman pertanian yang tidak banyak membutuhkan air lainya seperti jagung, ubi kayu, kacang hijau, kedelai dan kacang tanah. 


\section{KESIMPULAN}

Kesimpulan dari penelitian ini adalah (1)Keadaan pengairan di So Selence desa Belo kecamatan Palibelo kabupaten Bima hanya tersedia hanya pada musim hujan saja. (2). Petani di So Selence desa Belo kecamatan Palibelo kabupaten Bima pada musim hujan menanam padi. (3). Petani di So Selence desa Belo kecamatan Palibelo kabupaten Bima pada musim kemarau menanam sayur sayuran, buahbuahan kedelai, kacang tanah, kacang hijau dan jagung.

\section{Daftar Pustaka}

Arikunto, Suharsimi (2002) Metode Penelitian Kualitatif. Jakarta: Erlangga.

Djamali (2000) Manajemen Usahatani. Jember: Departemen Pendidikan Nasional Politeknik Negeri Jember Jurusan Manajemen Agribisnis.

Milles, Matthew B \& Michael Huberman (1992) Analisis Data Kualitatif. Jakarta: Penerbit Universitas Indonesia.

Moeloeng, Lexy (2002) Metodologi Penelitian Kualitatif. Bandung: PT Remaja Rosdakarya.

Mubyarto (1989) Politik Pertanian Dan Pembangunan Pedesaan. Jakarta: Penerbit Sinar Harapan.

Rachman (1999) Prosedur Penyelenggaraan Penelitian Kualitatif (Handout Mata Kuliah Metode Penelitian Kuatatif). Surabaya: UNTAG.

Rahim, 2007, Ekonomi Pertanian (Pengantar, Teori Dan Kasus) Yogyakarta: Seri AgriWawasan

Soekanto, Soeryono (2009) Sosiologi Suatu Pengantar. Jakarta: Rajawali Press.

Soekartawi, (2004) Pengantar Agroindustri. Jakarta: PT Raja Grafindo Persada, 